\title{
Manajemen Asuhan Keperawatan Jiwa Pada Ny J Dengan Masalah Defisit Perawatan Diri Di Kota Dumai - Riau
}

\author{
Septyana Ndaha
}

tyanan97@gmail.com

\section{BAB 1}

PENDAHULUAN

\subsection{Latar Belakang}

Kesehatan jiwa merupakan kondisi seseorang dimana individu tersebut mampu berkembang secara fisik, mental, spiritual, dan social sehingga individu tersebut menyadari kemampuannya sendiri, dapat mengatasi tekanan, dapat bekerja secara produktif dan individu tersebut mampu memberikan kontribusi untuk komunitasnya (Pardede, 2020). Atau dapat dikatakan bahwa individu dikatakan sehat jiwa apabila berada dalam kondisi fisik, mental dan social yang terbebas dari gangguan (penyakit) atau tidak dalam kondisi tertekan sehingga dapat mengendalikan stress yang timbul. Sehingga memungkinkan individu untuk hidup produktif, dan mampu melakukan hubungan social yang memuaskan (Nurhalimah, 2016).

Skizofrenia adalah sekelompok reaksi psikotik yang dapat mempengaruhi berbagai area fungsi individu, termasuk berfikir, berkomunikasi, merasakan serta menunjukkan emosi dan gangguan otak yang ditandai dengan pikiran kacau, waham, halusinasi serta perilaku aneh. Skizofrenia merupakan penyakit gangguan mental berat dan kronis yang menyerang 20 juta orang di seluruh dunia (Pardede, Ariyo, \& Purba, 2020).

Menurut Pardede (2019) mengatakan bahwa skizofrenia merupakan penyakit kronis, parah dan melumpuhkan, gangguan otak yang ditandai dengan pikiran kacau, waham, halusinasi dan perilaku aneh. Prevalensi skizofrenia diperkirakan sebesar 0,2\% meningkat menjadi 1,5\% setara untuk pria dan wanita di semua tingkatan usia (Pardede, Hamid, \& Putri, 2020). 
Menurut World Health Organization (WHO, 2013), prevalensi masalah kesehatan jiwa saat ini cukup tinggi, 25\% dari penduduk dunia pernah menderita masalah kesehatan jiwa, $1 \%$ diantaranya merupakan gangguan jiwa berat, potensi seseorang mudah terserang gangguan jiwa memang sangat tinggi, sekotar 450 juta orang diseluruh dunia terkena dampak permasalahan jiwa, saraf maupun perilaku. Riset Kesehatan Jiwa (2013) jumlah klien gangguan jiwa di Indonesia semakin bertambah, terdapat 14,1\% penduduk Indonesia yang mengalami gangguan jiwa mulai dari yang ringan hingga berat (Pinedendi et al., 2016).

Data yang diperoleh di Amerika Serikat setiap tahunnya, terdapat 300 ribu klien skizofrenia yang mengalami episode akut, hampir 20\%-50\% klien skizofrenia yang melakukan percobaan bunuh diri, dan 10\% diantaranya berhasil meninggal. Dapat disimpulkan angka kematian klien skizofrenia di Amerika Serikat delapan kali lebih tinggi dari angka kematian penduduk. Sedangkan hasil RISKESDAS (2019) didapatkan bahwa hasil estimasi prevalensi orang yang pernah menderita skizofrenia di Indonesia sebesar 1,8 per 100 penduduk (Pardede \& Purba, 2020).

Perawatan diri atau personal hygiene merupakan tindakan dimana memelihara kebersihan dan kesehatan diri seseorang untuk kesejahteraan fisik maupun psikisnya. Seseorang dikatakan perawatan diri yang baik apabila orang tersebut dapt menjaga kebersihan tubuhnya yang meliputi kebersihan kulit, gigi dan mulut, rambut, mata, hidung dan telinga, kaki dan kuku, genitalia, serta kebersihan dan kerapihan dalam berpakaian. Perawatan diri sangat bergantung pada pribadi masing-masing dimana nilai individu dan kebiasaan untuk mengembangkannya. Kehidupan sehari-hari yang beraturan, menjaga kebersihan tubuh, makanan yang sehat, istirahat cukup dan mendapat perhatian (Pinedendi et al., 2016).

Deficit perawatan diri merupakan suatu keadaan dimana seseorang mengalami hambatan ataupun gangguan dalam kemampuan untuk melakukan atau menyelesaikan aktivitas perawatan diri, seperti mandi, berpakaian, makan, dan eliminasi untuk dirinya sendiri (Tumanduk, Messakh, \& Sukardi, 2018).

Defisit perawatan diri menurut Orem merupakan ketidakmampuan seseorang untuk melakukan perawatan diri secara adekuat sehingga dibutuhkan beberapa system yang dapat 
membantu klien memenuhi kebutuhannya. Dalam hal ini Orem mengidentifikasi lima metode yang dapat menyelesaikan masalah defisit perawatan diri yaitu bertindak untuk orang lain, sebagai pembimbing orang lain, memberi dukungan, meningkatkan pengembangan lingkungan, dan mengajarkan pada orang lain (Prihadi \& Erlando, 2019).

Seseorang yang mengalami deficit perawatan diri dapat dilihat dari badan yang bau, kotor, berdaki, gigi kotor, kuku panjang, rambut kusut, sangat berantakan, ketidakmampuan dalam berdandan, kumis dan jenggot tidak rapi, pakaian tidak rapi, tidak beralas kaki, memakai barang yang tidak perlu dalam berpakaian, telanjang, makan dan minum yang tidak teratur, BAB dan BAK tidak pada tempatnya (Nurhalimah, 2016). Pada survey awal dalam pembuatan askep pada klien skizofrenia ini dilakukan di Kota Dumai - Riau yang ditemukan klien dengan deficit perawatan diri, dengan inisial nama $\mathrm{Ny}$. J. penyebab $\mathrm{Ny}$. J dijadikan sebagai subjek dalam askep ini dikarenakan klien belum mampu mengatasi deficit perawatan diri yang dialaminya.

\subsection{Rumusan Masalah}

Berdasarkan latar belakang masalah tersebut maka dapat dirumuskan masalah sebagai berikut : Asuhan Keperawatan Jiwa Pada Ny. J dengan Defisit Perawatan Diri di Kota Dumai, Riau.

\subsection{Tujuan Penulisan}

Adapun tujuannya sebagai berikut :

\subsubsection{Tujuan Umum}

Penulis mampu memberikan asuhan keperawatan jiwa pada Ny. J dengan Defisit Perawatan Diri di Kota Dumai, Riau.

\subsubsection{Tujuan Khusus}

a. Mahasiswa mampu mengetahui defenisi, tanda \& gejala, faktor penyebab, mekanisme koping, penatalaksanaan pada klien dengan Defisit Perawatan Diri.

b. Mahasiswa mampu melakukan pengkajian pada klien dengan Defisit Perawatan Diri.

c. Mahasiswa mampu menegakkan diagnosa atau masalah keperawatan pada $\mathrm{Ny}$. J dengan Defisit Perawatan Diri. 
d. Mahasiswa mampu menetapkan intervensi keperawatan secara menyeluruh pada $\mathrm{Ny}$. J dengan Defisit Perawatan Diri.

e. Mahasiswa mampu melakukan tindakan keperawatan yang nyata pada $\mathrm{Ny}$. J dengan Defisit Perawatan Diri.

f. Mahasiswa mampu mengevaluasi sebagai tolak ukur guna menerapkan asuhan keperawatan pada Ny. J dengan Defisit Perawatan Diri.

g. Mahasiswa mampu mendokumentasikan asuhan keperawatan pada Ny. J dengan Defisit Perawatan Diri. 


\section{BAB 2 \\ TINJAUAN TEORITIS}

\subsection{Konsep Dasar Defisit Perawatan Diri}

\subsubsection{Pengertian}

Herdman (2012) mengatakan bahwa deficit perawatan diri sebagai suatu gangguan didalam melakukan perawatan diri (kebersihan diri, berhias, makan, toileting). Sedangkan perawatan diri adalah kemampuan dasar manusia untuk memenuhi kebutuhannya untuk mempertahankan kehidupan, kesehatan, dan kesejahteraan sesuai dengan kondisi kesehatannya (Nurhalimah, 2016).

Deficit perawatan diri merupakan suatu keadaan dimana seseorang mengalami hambatan ataupun gangguan dalam kemampuan untuk melakukan atau menyelesaikan aktivitas perawatan diri, seperti mandi, berpakaian, makan, dan eliminasi untuk dirinya sendiri (Tumanduk, Messakh, \& Sukardi, 2018).

\subsubsection{Jenis-Jenis Defisit Perawatan Diri}

Menurut Nanda (2012), jenis perawatan diri terdiri dari :

a. Deficit perawatan diri : Mandi

Hambatan kemampuan untuk melakukan atau menyelesaikan mandi/beraktivitas perawatan diri untuk diri sendiri.

b. Deficit perawatan diri : berhias

Hambatan kemampuan untuk melakukan atau menyelesaikan aktivitas berpakaian dan berhias untuk diri sendiri.

c. Deficit perawatan diri : makan/minum

Hambatan kemampuan untuk melakukan atau menyelesaikan aktivitas makan dan minum secara mandiri.

d. Deficit perawatan diri : BAB/BAK

Hambatan kemampuan untuk melakukan atau menyelesaikan aktivitas eliminasi sendiri.

\subsubsection{Etiologi}


a. Factor predisposisi (Nurhalimah, 2016).

1) Biologis, dimana deficit perawatan diri disebabkan oleh adanya penyakit fisik dan mental yang disebabkan klien tidak mampu melakukan kperawatan diri dan dikarenakan adanya factor herediter dimana terdapat anggota keluarga yang mengalami gangguan jiwa.

2) Psikologis, adanya factor perkembangan yang memegang peranan yang tidak kalah penting, hal ini dikarenakan keluarga terlalu melindungi dan memanjakan individu tersebut sehingga perkembangan inisiatif menjadi terganggu. Klien yang mengalami deficit perawatan diri dikarenakan kemampuan realitas yang kurang yang menyebabkan klien tidak peduli terhadao dir dan lingkungannya termasuk perawatan diri.

3) Social, kurangnya dukungan social dan situasi lingkungan yang mengakibatkan penurunan kemampuan dalam merawat diri.

b. Factor presipitasi

Faktor presipitasi yang menyebabkan deficit perawatan diri yaitu penurunan motivasi, kerusakan kognitif/persepsi, cemas, lelah, lemah yang menyebabkan individu kurang mampu melakukan perawatan diri.

Menurut Rochmawati (2013), factor-faktor yang mempengaruhi personal hygiene adalah :

1) Body Image

Gambaran individu terhadap dirinya sangat mempengaruhi kebersihan diri misalnya dengan adanya perubahan fisik sehingga individu tidak peduli dengan kebersihan dirinya.

2) Praktik Sosial

Pada anak-anak yang selalu dimanja dalam kebersihan diri, maka kemungkinan akan terjadi perubahan pola personal hygiene.

3) Status Sosial Ekonomi

Personal hygiene memerlukan alat dan bahan seperti sabun, pasta gigi, sikat gigi, shampoo, alat mandi semuanya yang memerlukan uang untuk menyediakannya

4) Pengetahuan 
Pengetahuan personal hygiene sangat penting karena pengetahuan yang baik dapat meningkatkan kesehatan. Misalnya pad aklien penderita DM, ia harus menjaga kebersihan kakinya.

5) Budaya

Disebagian masyarakat jika individu sakit tertentu tidak boleh dimandikan.

6) Kebiasaan Seseorang

Ada kebiasaan orang yang menggunakan produk tertentu dalam perawatan diri seperti pengguanaan sabun, shampoo dan lain-lain.

Dampak yang sering timbul pada masalah personal hygiene :

1) Dampak Fisik

Banyak gangguan kesehatan yang diderita seseorang karena tidak terpeliharanya kebersihan perorangan dengan baik, gangguan fisik yang sering terjadi adalah : Gangguan integritas kulit, gangguan membrane mukosa mulut, infeksi pada mata dan telinga dan gangguan fisik pada kuku.

2) Dampak Psikososial

Masalah social yang berhubungan dengan personal hygiene adalah gangguan kebutuhan rasa nyaman, kebutuhan dicintai dan mencintai, kebutuhan harga diri dan gangguan interaksi social.

\subsubsection{Tanda Dan Gejala}

Menurut Jalil (2015), tanda dan gejala defisit perawatan diri terdiri dari :

a. Data subjektif

Klien mengatakan :

1) Malas mandi

2) Tidak mau menyisir rambut

3) Tidak mau menggosok gigi

4) Tidak mau memotong kuku

5) Tidak mau berhias/berdandan

6) Tidak bisa/tidak mau menggunakan alat mandi/kebersihan diri

7) Tidak menggunakan alat makan dan minum saat makan dan minum

8) $\mathrm{BAB}$ dan BAK sembarangan 
9) Tidak membersihkan diri dan tempat $\mathrm{BAB}$ dab BAK

10) Tidak mengetahui cara perawatan diri yang benar

b. Data objektif

1) Badan bau, kotor, berdaki, rambut kotor, gigi kotor, kuku panjang.

2) Tidak menggunakan alat mandi pada saat mandi dan tidak mandi dengan benar.

3) Rambut kusut, berantakan, kumis dan jenggot tidak rapi, serta tidak mampu berdandan.

4) Pakaiann tidak rapi, tidak mampu memilih, mengambil, memakai, mengencangkan dan memindahkan pakaian, tidak memakai sepatu, tidak mengkancingkan baju atau celana.

5) Memakai barang-barang yang tidak perlu dlaam berpakaian, mis: memakai pakaian berlapis-lapis, penggunaa pakaian yang tidak sesuai. Melepas barang-barang yang perlu dalam berpakaian, mis: telanjang.

6) Makan dan minum sembarangan dan berceceran, tidak menggunakan alat makan, tidak mampu menyiapkan makanan, memindahkan makanan kea lat makan, tidak mampu memegang alat makan, membawa makanan dari piring ke mulut, mengunyah, menelan makanan secara aman dan menghabiskan makanan.

7) $\mathrm{BAB}$ dan $\mathrm{BAK}$ tidak pada tempatnya, tidak membersihkan dir setelah BAB dan BAK, tidak mampu menjaga kebersihan toilet dan menyiram toilet setelah BAB dan BAK.

\subsubsection{Proses Terjadinya}

Data yang biasa ditemukan dalam deficit perawatan diri (Hastuti, 2018) adalah :

a. Data Subjektif

1) Klien merasa lemah

2) Malas untuk beraktivitas

3) Merasa tidak berdaya

b. Data Objektif

1) Rambut kotor, acak-acakan 
2) Badan dan pakaian kotor dan bau

3) Mulut dan gigi bau

4) Kulit kusan dan kotor

5) Kuku panjang dan tidak terawat

\subsubsection{Rentang Respon Kognitif}

Menurut Keliat (2014), rentang respon perawatan diri pad aklien adalah sebagai berikut :

Gambar 1 : Rentang Respon Kognitif

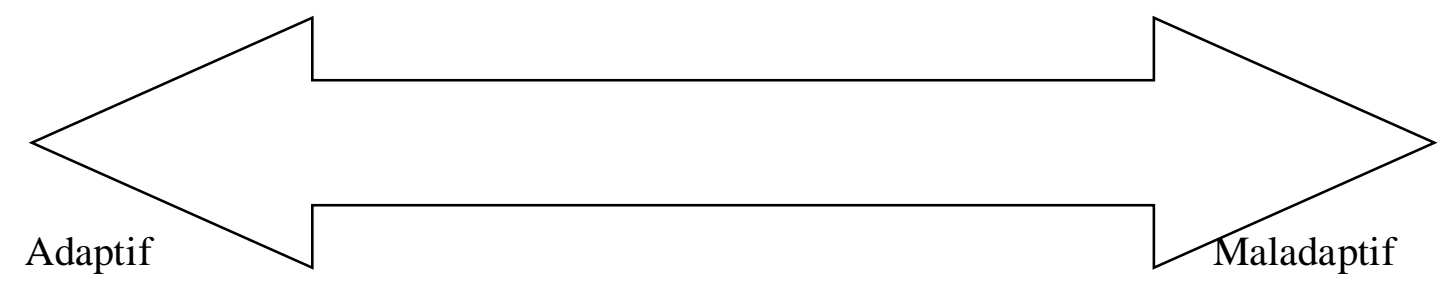

\begin{tabular}{|l|l|l|l|}
\hline \multicolumn{5}{|l|}{} & \multicolumn{3}{|c|}{} \\
\hline $\begin{array}{l}\text { Pola perawatan diri } \\
\text { seimbang }\end{array}$ & $\begin{array}{l}\text { Kadang perawatan diri, } \\
\text { kadang tidak }\end{array}$ & $\begin{array}{l}\text { Tidak } \\
\text { perawatan saat stress }\end{array}$ \\
\hline
\end{tabular}

Keterangan :

a. Pola perawatan diri seimbang, saat klien mendapatkan stressor dan mampu untuk berperilaku adaptif, maka pola perawatan yang dilakukan klien seimbang, klien masih melakukan perawatan diri.

b. Kadang perawatan kadang tidak, saat klien mendapatkan stressor kadang-kadang klien tidak memperhatikan perawatan dirinya.

c. Tidak melakukan perawatan diri, klien mengatakan dia tidak peduli dan tidak bisa melakukan perawatan saat stressor. 


\subsubsection{Mekanisme Koping}

Menurut (Sutria, 2020), mekanisme koping berdasarkan penggolongan di bagi menjadi 2 yaitu :

a. Mekanisme koping adaptif

Mekanisme koping yang mendukung fungsi integrasi pertumbuhan belajar dan mencapi tujuan. Kategori ini adalah klien bisa memenuhi kebutuhan perawatan diri secara mandiri.

b. Mekanisme koping maladaptive

Mekanisme koping yang menghambat fungsi integrasi, memecah pertumbuhan, menurunkan otonomi dan cenderung menguasai lingkungan. Kategorinya adalah tidak ingin merawat diri.

\subsubsection{Penatalaksanaan}
a. Meningkatkan kesadaran dan kepercayaan diri
b. Membimbing dan menolong klien merawat diri
c. Ciptakan lingkungan yang mendukung

\subsubsection{Manifestasi Klinis}

Menurut (Putra, 2019) tanda dan gejala klien dengan defisit perawatan diri adalah :

1. Subyektif
a. Menyatakan tidak ada keingin mandi secara teratur
b. Perawatan diri harus dimotivasi
c. Menyatakan Bab/bak disembarangan tempat
d. Menyatakan tidak mampu menggunakan alat bantu makan

2. Obyektif
a. Tidak mampu membersihkan badan
b. Berpakaian secara benar
c. Tidak mampu melaksanakan kebersihan yang sesuai
d. Setelah melakukan toileting
e. Makan hanya beberapa suap darri piring/porsi tidak habis 


\subsection{Konsep Asuhan Keperawatan Defisit Perawatan Diri}

\subsubsection{Pengkajian}

Defisit Perawatan Diri pada klien dengan ganngguan jiwa terjadi akibat ada perubahan proses pikir sehingga kemampuan untuk melakukan perawatan diri tampak dari ketidakmampuan merawat kebersihan diri makan secara mandi,berhias diri secara mandiri dan eliminasi (buang air besar/buang air kecil) secara mandiri. (Hastuti, 2018).

a. Alasan masuk

Terdiri dari : nama klien, umur, jenis kelamin, alamat, agama, pekerjaan, tanggal masuk, alasan masuk, nomor rekam medic, keluarga yang dapat dihubungi.

b. Alasan masuk

Merupakan penyebab klien atau keluarga datang, atau dirawat dirumah sakit. Biasanya masalah yang dialami klien yaitu senang menyendiri, tidak mau banyak berbicara dengan orang lain, terlihat murung, penampilan acak-acakan, tidak peduli dengan diri sendiri dan mulai mengganggu orang lain.

c. Factor predisposisi

1) Pada umumnya klien pernah mengalami gangguan jiwa di masa lalu.

2) Penyakit kronis yang menyebabkan klien tidak mampu melakukan perawatan diri.

3) Pengobatan sebelumnya kurang berhasil

4) Harga diri rendah, klien tidak mempunyai motivasi untuk merawat diri.

5) Pengalaman masa lalu yang tidak menyenangkan, yaitu perasaan ditolak, dihina, dianiaya dan saksi penganiayaan.

6) Ada anggota keluarga yang pernah mengalami gangguan jiwa.

7) Pengalaman masa lalu yang tidak menyenangkan yaitu kegagalan yang dapat menimbulkan frustasi

d. Pemeriksaan Fisik

Pemeriksaan TTV, pemeriksaan head to toe yang merupakan penampilan klien yang kotor dan acak-acakan.

e. Psikososial

1) Genogram 
Menggambarkan klien dan anggota keluarga klien yang mengalami gangguan jiwa, dilihat dari pola komunikasi, pengambilan keputusan dan pola asuh.

2) Konsep Diri

a) Citra Tubuh

Persepsi klien mengenai tubuhnya, bagian tubuh yang disukai, reaksi klien mengenai tubuh yang disukai maupun tidak disukai.

b) Identitas Diri

Kaji status dan posisi pasien sebelum klien dirawat, kepuasan paien terhadap status dan posisinya, kepuasan klien sebagai lakilaki atau perempuan.

c) Peran Diri

Meliputi tugas atau peran klien didalam keluarga/pekerjaan/kelompok maupun masyarakat, kemampuan klien didalam melaksanakan fungsi atupun perannya, perubahan yang terjadi disaat klien sakit maupun dirawat, apa yang dirasakan klien akibat perubahan yang terjadi.

d) Ideal Diri

Berisi harapan paien akan keadaan tubuhnya yang ideal, posisi, tugas, peran dalam keluarga, pekerjaan/sekolah, harapan klien akan lingkungan sekitar,dan penyakitnya.

e) Harga Diri

Kaji klien tentang hubungan dengan orang lain sesuai dengan kondisi, dampak pada klien yang berhubugan dengan orang lain, fungsi peran yang tidak sesuai dengan harapan, penilaian klien tentang pandangan atau penghargaan orang lain.

f) Hubungan Sosial

Hubungan klien dengan orang lain akan sangat terganggu karena penampilan klien yang kotor yang mengakibatkan orang sekitar menjauh dan menghidnari klien. Terdapat hambatan dalam berhubungan dengan orang lain. 
g) Spiritual

Nilai dan keyakinan serta kegiatan ibadah klien terganggu dikarenakan klien mengalami gangguan jiwa.

h) Status Mental

i. Penampilan

Penampilan klien sangat tidak rapi, tidak mengetahui caranya berpakaian dan penggunaan pakaian tidak sesuai.

ii. Cara bicara/Pembicaraan

Cara bicara klien yang lambat, gagap, sering terhenti/bloking, apatis serta tidak mampu memulai pembicaraan.

iii. Aktivitas motorik

Biasanya klien tamoak lesu, gelisah, tremor dan kompulsif.

iv. Alam perasaan

Klien tamoak sedih, putus asa, merasa tidak berdaya, rendah diri dan merasa dihina.

v. Afek

Klien tampak datar, tumpul, emosi klien berubah-ubah, kesepian, apatis, depresi/sedih dan cemas.

vi. Interaksi saat wawancara

Respon klien saat wawancara tidak kooperatif, mudah tersinggung, kontak kurang serta curiga yang menunjukkan sikap ataupun peran tidak percaya kepada pewawancara/orang lain.

vii. Persepsi

Klien berhalusinasi mengenai ketakutan terhadap hal-hal kebersihan diri baik halusinasi pendengaran, penglihatan dan perabaan yang membuat klien tidak ingin membersihkan diri dan klien mengalami depersonalisasi.

viii. Proses pikir 
Bentuk pikir klien yang otistik, dereistik, sirkumtansial, terkadang tangensial, kehilanagn asosiasi, pembicaraan meloncat dari topic dann terkadang pembicaraan berhenti tiba-tiba.

i) Kebutuhan Klien Pulang

1. Makan

Klien kurang makan, cara makan klien yang terganggu serta psien tidak memiliki kemampuan untuk menyiapkan dan membersihkan alat makan

1. Berpakaian

Klien tidak mau mengganti pakaian, tidak bisa memakai pakaian yang sesuai dan berdandan.

2. Mandi

Klien jarang mandi, tidak tahu cara mandi, tidak gosok gigi, mencuci rambut, menggunting kuku, tubuh klien tampak kusan dan badan klien mengeluarkan aroma bau.

3. ВАВ/BAK

Klien BAB/BAK tidak pada tempatnya seperti di temoat tidur dan klien tidak dapat membersihkan BAB/BAKnya.

4. Istirahat

Istirahat klien terganggu dan tidak melakukan aktivitas apapun setelah bangun tidur.

5. Penggunaan obat

Jika klien mendapat obat, biasanya klien minum obat tidak teratur.

6. Aktivitas di Rumah

Klien tidak mampu melakukan semua aktifitas di dalam rumah karena klien selalu merasa malas.

j) Mekanisme Koping

1. Adaptif 
Klien tidak mau berbicara dengan orang lain, tidak bisa menyelesaikan masalah yangada, klien tidak mampu berolahraga karena klien selalu malas.

2. Maladaptive

Klien bereaksi sangat lambat terkadang berlebihan, klien tidak mau bekerja sama sekali, selalu menghindari orang lain.

3. Masalah Psikososial dan Lingkungan

Klien mengalami masalah psikososial seperti berinteraksi dengan orang lain dan lingkungan. Hal ini disebabkan oleh kurangnya dukungan dari keluarga, pendidikan yang kurang, masalah dengan social ekonomi dan pelayanan kesehatan,

4. Pengetahuan

Klien deficit perawatan diri terkadang mengalami gangguan kognitif sehingga tidak mampu mengambil keputusan.

k) Sumber Koping

Merupakan evaluasi terhadap pilihan koping dan strategi seseorang. Individu dapat mengatasi stress da ansietas dengan menggunakan sumber koping yang terdapat di lingkungannya. Sumber koping ini dijadikan modal untuk menyelesaikan masalah. 


\section{BAB 3 \\ TINJAUAN KASUS}

\subsection{Identitas Klien}

$\begin{array}{lll}\text { Inisial } & : & \text { Ny. J } \\ \text { Jenis Kelamin } & : & \text { Perempuan } \\ \text { Umur } & : & 65 \text { tahun } \\ \text { Agama } & : & \text { Kristen } \\ \text { Status } & : & \text { Menikah } \\ \text { Tanggal Pengkajian } & : & 16 \text { February } 2021 \\ \text { Diagnose Medis } & : & \text { Defisit Perawatan Diri }\end{array}$

\subsection{Faktor Predisposisi}

Klien sebelumnya pernah mengalami gangguan jiwa sekitar \pm 3 tahun yang lalu tepatnya pada tahun 2017 dan pulang kerumah dalam keadaan baik. Saat dirumah, klien selalu merasa kesepian dikarenakan anak-anaknya tidak mau berkunjung untuk melihatnya sehingga klien merasa tidak diperdulikan dan diperhatikan oleh anak-anaknya. Kemudian sakit klien kambuh kembali saat mengetahui anaknya membuat masalah, klien semakin depresi dan akhirnya klien malas mengurus dirinya sendiri. Keluarga klien tidak ada yang pernah mengalami gangguan jiwa

\section{Masalah Keperawatan : Defisit Perawatan Diri}

\subsection{Fisik}

Klien mengeluh dengan badannya yang kotor dan bau, lalu klien juga mengeluh lututnya sakit ketika berjalan, saat dilakukan TTV didapatkan hasil TD : 140/90mmHg ; $\mathrm{N}: 80 \mathrm{x} / \mathrm{I}$ ; $\mathrm{S}: 36,7^{0} \mathrm{C}$; P : 16x/i. Klien memiliki TB : 145cm dan BB : $68 \mathrm{~kg}$.

\subsection{Psikososial}




\subsubsection{Genogram}

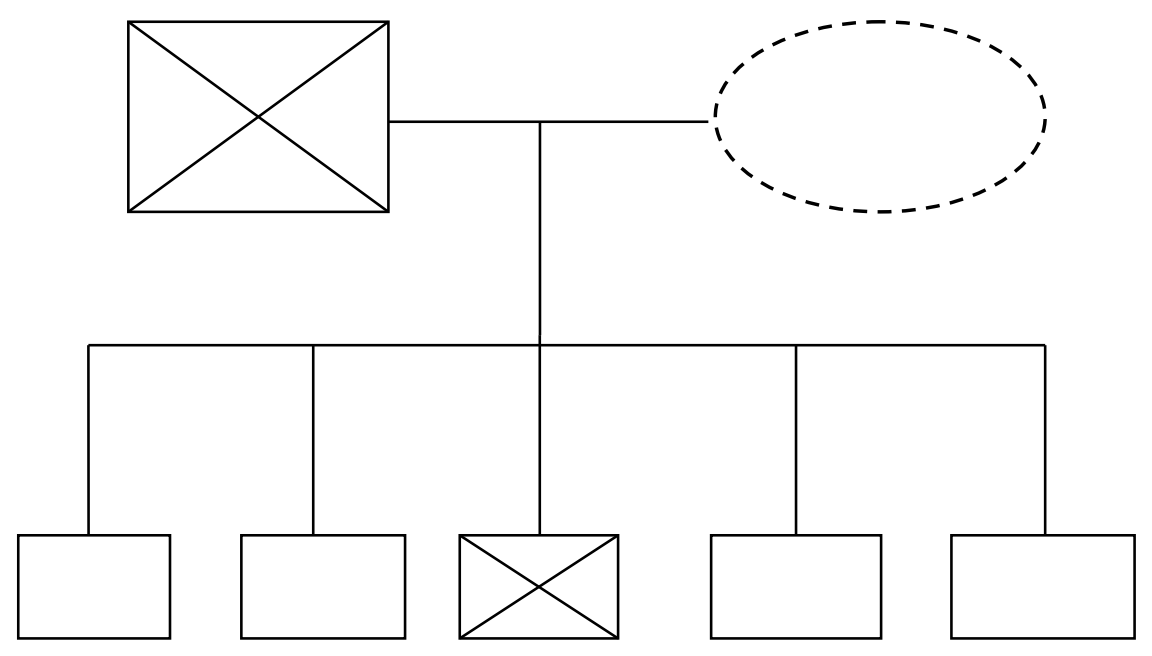

Keterangan :

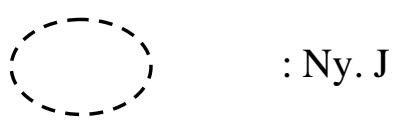

$\square \quad$ : Laki-laki

$\$$ : Meninggal

Penjelasan :

Klien sudah menikah dan memiliki 5 orang anak laki-laki.

\subsubsection{Konsep Diri}


a. Gambaran Diri : Klien sangat tidak menyukai badannya yang bau dan kotor.

b. Identitas : Klien seorang wanita tamatan SD.

c. Peran : Klien merupakan seorang ibu rumah tangga.

d. Ideal Diri : Klien sangat ingin sembuh.

e. Harga Diri : Klien mengatakan merasa gagal menjadi seorang ibu untuk anakanaknya.

\section{Masalah Keperawatan : Harga Diri Rendah Kronis}

\subsubsection{Hubungan Sosial}

Klien mengatakan orang yang berarti dalam hidupnya adalah keluarganya (suami dan anak-anaknya). Klien tidak mengikuti kegiatan di kelompok/masyarakat. Klien mengatakan malu jika bertemu dengan orang-orang karena merasa bau dan kotor. Klien juga mengatakan merasa gagal menjadi seorang ibu untuk anak-anaknya.

\section{Masalah Keperawatan : Isolasi Sosial}

\subsubsection{Spiritual}

a. Nilai dan Keyakinan : klien menganut agama Kristen.

b. Kegiatan ibadah : semenjak sakit klien kambuh, dalam sebulan ini belum ada mengikuti kegiatan ibadah.

\subsubsection{Status Mental}

a. Tingkat kesadaran : Compos mentis

b. Penampilan : klien tidak rapi, klien mengatakan malas mandi dan gosok gigi, klien mengatakan sudah 2 minggu lebih tidak mengganti baju dan celana, hal ini dapat dilihat pada saat awal pengkajian berlangsung.

\section{Masalah Keperawatan : Defisit Perawatan Diri}

c. Pembicaraan : selama pengkajian, klien sangat mudah untuk diajak berbicara.

d. Alam perasaan : klien terlihat sedih karena merasa tidak diperhatikan oleh anaknya. Masalah keperawatan : Harga Diri Rendah

e. Afek : klien sangat jarang berbicara jika tidak ada yang mangajak klien mengobrol dan klien hanya berbicara seperlunya saja. 


\section{Masalah Keperawatan : Isolasi Sosial}

f. Interaksi selama wawancara : selama di wawancara saat pengkajian, klien tampak kooperatif dan kontak mata mudah beralih kearah lain.

g. Persepsi : klien mengatakan merasa malas untuk mandi karena menurutnya mandi ataupun tidak mandi maka tetap tidak akan ada yang memperhatikannya.

\section{Masalah Keperawatan : Defisit Perawatan Diri}

h. Proses pikir : pembicaraan klien sesuai dengan pertanyaan perawat. Tidak ditemukan adanya masalah keperawatan.

i. Isi pikir : klien tidak mengalami gangguan daya pikir saat dilakukan wawancara

j. Tingkat kesadaran : klien tidak mengalami gangguan orientasi waktu, orang dan tempat.

k. Memori : klien mampu menceritakan kejadian di masa lalu dan yang baru terjadi

\subsection{Mekanisme Koping}

a. Adaptif : ketika ada masalah, maka klien hanya akan memendam sendiri dan tidak menceritakannya dengan siapa pun.

b. Maladaptive : disaat ada masalah klien selalu menghidarinya dan lebih baik tidur daripada memikirkannya.

\subsection{Masalah Psikososial Dan Lingkungan}

Klien mengatakan merasa malu untuk bertemu orang karena kondisi tubuhnya yang bau dan kotor.

\subsection{Analisis Data}




\begin{tabular}{|c|c|c|}
\hline NO & DO/DS & MASALAH KEPERAWATAN \\
\hline 1 & $\begin{array}{l}\text { DS : } \\
\text { - } \text { Klien mengatakan malas untuk } \\
\text { merawat dirinya karena menurutnya } \\
\text { mandi ataupun tidak mandi tetap tidak } \\
\text { akan yang memperhatikannya. } \\
\text { - } \text { Klien hanya mengganti baju jika } \\
\text { merasa ingin, jika tidak maka } \\
\text { pakaiannya akan terus ia pakai. } \\
\text { - Klien mengatakan tidak pernah } \\
\text { mencuci tangan saat makan dan ketika } \\
\text { selesai makan klien hanya melap di } \\
\text { pakaiannya saja, } \\
\text { - Klien mengatakan jika BAB/BAK } \\
\text { hanya menyiramnya begitu saja. } \\
\text { DO : } \\
\text { - } \\
\text { Klien tampak kotor dan sangat bau. } \\
\text { Klien sering memakai pakaian yang } \\
\text { sama tiap harinya dan berbau } \\
\text { Kuku klien tampak sangat kotor dan } \\
\text { panjang } \\
\text { kuning klien tampak kotor dan giginya }\end{array}$ & Deficit perawatan diri \\
\hline 2 & $\begin{array}{ll}\text { DS : } & \\
\text { - } & \text { Klien mengatakan merasa gagal } \\
& \text { menjadi seorang ibu untuk anak- } \\
& \text { anaknya } \\
\text { - } & \text { Klien mengatakan malu bertemu } \\
& \text { dengan orang lain karena merasa kotor }\end{array}$ & Harga Diri Rendah \\
\hline
\end{tabular}




\begin{tabular}{|c|c|c|}
\hline & $\begin{array}{ll} & \text { dan bau } \\
\text { DO : } & \\
\text { - } & \text { Klien tampak sering sedih dan murung } \\
\text { - } & \text { Klien berbicara seoerlunya saja jika } \\
& \text { ada yang mengajaknya berbicara }\end{array}$ & \\
\hline 3 & $\begin{array}{ll}\text { DO : } & \\
\text { - } & \text { Klien mengatakan tidak memiliki } \\
& \text { teman dekat dan lebih senang } \\
& \text { menyendiri saja } \\
\text { DS : } & \\
\text { - } & \text { Klien tampak sering melamun } \\
\text { - } & \text { Klien sering menghindari orang lain } \\
\text { - } & \text { Klien tampak jarng berbicara dengan } \\
& \text { orang lain }\end{array}$ & Isolasi Sosial \\
\hline
\end{tabular}

\subsection{Rumusan Masalah}
a. Deficit perawatan diri
b. Harga diri rendah
c. Isolasi Sosial

3.9 Pohon Masalah 


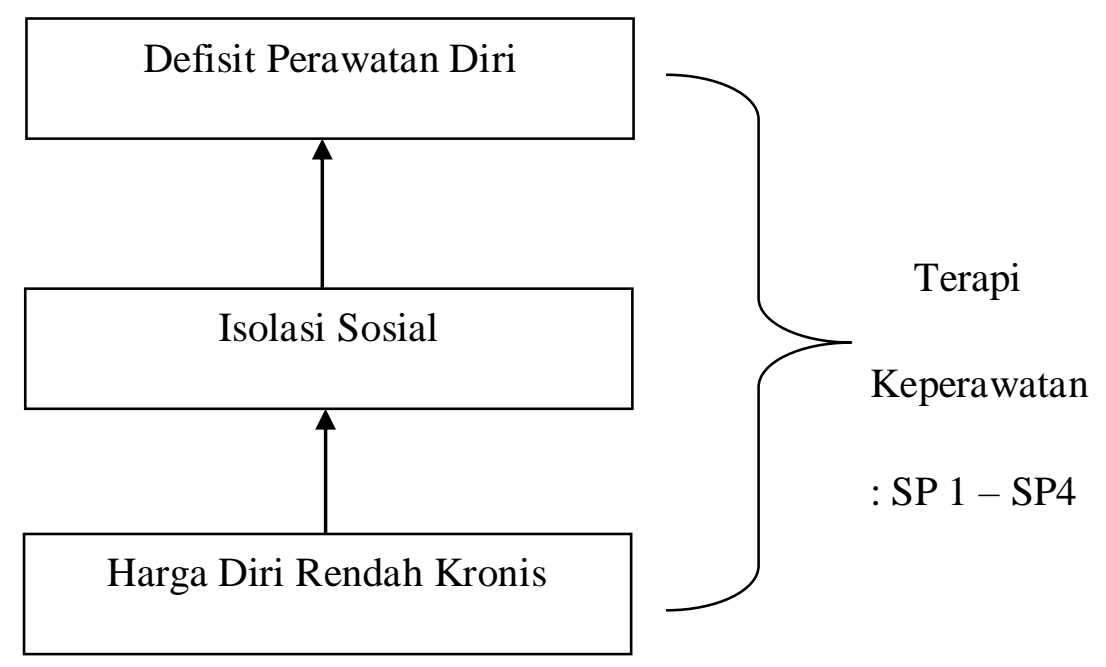

\subsection{Diagnosa Prioritas}

Defisit Perawatan Diri

\subsection{Intervensi Keperawatan}




\begin{tabular}{|c|c|c|c|}
\hline DX & TUJUAN & KRITERIA HASIL & INTERVENSI \\
\hline \multirow{4}{*}{$\begin{array}{c}\text { Defisit } \\
\text { Perawatan } \\
\text { Diri }\end{array}$} & $\begin{array}{l}\text { SP 1 : } \\
\text { Klien mampu } \\
\text { melakukan kebersihan } \\
\text { diri secara mandiri }\end{array}$ & $\begin{array}{llll}\text { Klien } & \text { mau } & \text { mandi } \\
\text { minimal } & 2 & \text { kali } & \text { dalam } \\
\text { sehari } & & & \end{array}$ & $\begin{array}{l}\text { SP 1: } \\
\text { Melatih cara } \\
\text { perawatan diri : } \\
\text { Mandi }\end{array}$ \\
\hline & $\begin{array}{l}\text { SP 2: } \\
\text { Klien mampu } \\
\text { melakukan berhias atau } \\
\text { berdandan secara baik }\end{array}$ & $\begin{array}{ll}\text { - } & \text { Penampilan } \\
\text { tampak } & \text { rapi, } \\
\text { bersih, } & \text { tidak } \\
\text { berbau } & \\
\text { - } & \text { Mampu } \\
\text { mengeringkan } \\
\text { badan setelah } \\
\text { mandi }\end{array}$ & $\begin{array}{l}\text { SP 2: } \\
\text { Melatih cara } \\
\text { perawatan diri : } \\
\text { Berhias }\end{array}$ \\
\hline & $\begin{array}{l}\text { SP 3: } \\
\text { Klien mampu mencuci } \\
\text { tangan sebelum dan } \\
\text { sesudah makan }\end{array}$ & $\begin{array}{l}\text { Klien mampu mencuci } \\
\text { tangan sebelum dan } \\
\text { sesudah makan }\end{array}$ & $\begin{array}{l}\text { SP 3: } \\
\text { Melatih cara } \\
\text { perawatan diri : } \\
\text { Makan/Minum }\end{array}$ \\
\hline & $\begin{array}{lr}\text { SP } 4 \text { : } & \\
\text { Klien mampu mencuci } \\
\text { tangan } \\
\text { BAB/BAK }\end{array}$ & $\begin{array}{l}\text { Klien mampu mencuci } \\
\text { tangan menggunakan } \\
\text { sabun setelah BAB/BAK }\end{array}$ & $\begin{array}{l}\text { SP 4: } \\
\text { Melatih cara } \\
\text { perawatan diri : } \\
\text { BAB/BAK }\end{array}$ \\
\hline
\end{tabular}

\subsection{Implementasi Dan Evaluasi}




\begin{tabular}{|c|c|c|}
\hline HaI & Implementasi & Evaluasi \\
\hline $\begin{array}{c}\text { Kamis, } \\
18 / 02 / 21 \\
\text { SP } 1 \\
(08.30 \\
\text { WIB })\end{array}$ & $\begin{array}{l}\text { Data: } \\
\text { Badan klien tampak kotor } \\
\text { dan bau, kuku jari tangan } \\
\text { dan kaki panjang dan kotor, } \\
\text { baju sangat kotor } \\
\text { Tindakan Keperawatan : } \\
\text { Sp } \quad \text { : Melatih cara } \\
\text { perawatan diri : mandi } \\
\text { 1. Membina hubungan } \\
\text { saling percaya } \\
\text { 2. Jelaskan pentingnya } \\
\text { kebersihan diri } \\
\text { 3. Jelaskan cara dan alat } \\
\text { kebersihan diri. } \\
\text { 4. Latih man menjaga } \\
\text { kebersihan diri } \\
\text { mandi, ganti pakaian, } \\
\text { rambut, potong kuku. }\end{array}$ & $\begin{array}{l}\text { S: klien sangat antusias } \\
\text { 1. Memperkenalkan diri } \\
\text { 2. Klien mengerti pentingnya kebersihan } \\
\text { dirinya. } \\
\text { 3. Klien merasa senang setelah dibantu. } \\
\text { O : } \\
\text { Klien tampak antusias saat mendapatkan } \\
\text { informasi dari perawat. } \\
\text { A : } \\
\text { Masalah teratasi, klien mau mandi dan } \\
\text { membersihkan diri. } \\
\text { P : } \\
\text { Intervensi dilanjutkan degan topic cara } \\
\text { berdandan yang baik }\end{array}$ \\
\hline & $\begin{array}{l}\text { Data: } \\
\text { Rambut berantakan, wajah } \\
\text { kusam } \\
\text { Tindakan Keperawatan : } \\
\text { Sp } \mathbf{2} \text { : Melatih cara } \\
\text { perawatan diri : berhias } \\
\text { 1. Evaluasi kegiatan Sp } \\
\text { 1. Beri pujian } \\
\text { 2. Jelaskan }\end{array}$ & $\begin{array}{l}\text { S : } \\
\text { Klien mampu menyebutkan dan } \\
\text { mempraktekkan secara mandiri cara } \\
\text { berdandan yang baik. } \\
\text { O : } \\
\text { Klien tampak sudah bisa untuk berdandan } \\
\text { dengan baik }\end{array}$ \\
\hline
\end{tabular}




\begin{tabular}{|c|c|c|}
\hline & $\begin{array}{l}\text { berdandan } \\
\text { 3. Latih cara berdandan } \\
\text { setelah } \\
\text { membersihkan diri : } \\
\text { sisiran, rias muka } \\
\text { untuk wanita }\end{array}$ & $\begin{array}{l}\text { P : } \\
\text { Intervensi dilanjutkan dengan topic cara } \\
\text { makan/minum yang baik }\end{array}$ \\
\hline $\begin{array}{l}\text { SP } 3 \\
(08.00 \\
\text { WIB })\end{array}$ & $\begin{array}{l}\text { Data: } \\
\text { Klien tidak pernah mencuci } \\
\text { tangan sebelum dan sesudah } \\
\text { makan } \\
\text { Tindakan Keperawatan : } \\
\text { Sp } \quad 3 \text { : Melatih cara } \\
\text { perawatan diri } \\
\text { makan/minum } \\
\text { 1. Evaluasi kegiatan Sp } \\
\text { 1 dan 2. Beri pujian } \\
\text { 2. Jelaskan cara dan alat } \\
\text { makan dan minum. } \\
\text { 3. Latih cara makan dan } \\
\text { minum yang baik. }\end{array}$ & $\begin{array}{l}\text { S : } \\
\text { Klien sangat antusias } \\
\text { O : } \\
\text { Klien tampak antusias dan saat makan klien } \\
\text { sudah bisa. } \\
\text { A : } \\
\text { Masalah teratasi } \\
\text { P : } \\
\text { Intervensi dilanjutkan dengan topic cara } \\
\text { BAB/BAK yang baik dan benar }\end{array}$ \\
\hline WIB) & $\begin{array}{l}\text { Data: } \\
\text { Badan klien sangat bau dan } \\
\text { kotor } \\
\text { Tindakan Keperawatan : } \\
\text { Sp } 4 \text { : Melatih cara } \\
\text { perawatan diri : BAB/BAK } \\
\text { 1. Evaluasi kegiatan Sp } \\
\text { 3. Beri pujian } \\
\text { 2. Jelaskan cara BAB }\end{array}$ & $\begin{array}{l}\text { S: } \\
\text { Klien mampu menjelaskan kembali cara } \\
\text { BAB/BAK yang baik. } \\
\text { A : } \\
\text { 1. Tujuan telah tercapai } \\
\text { 2. Klien sudah dapat makan dan minum } \\
\text { dengan baik serta BAK/BAB dengan } \\
\text { baik. } \\
\mathbf{P :}\end{array}$ \\
\hline
\end{tabular}




\begin{tabular}{|l|l|l|}
\hline & $\begin{array}{l}\text { dan BAK yang baik } \\
\text { 3. } \begin{array}{l}\text { Latih BAB dan BAK } \\
\text { yang baik }\end{array}\end{array}$ & Intervensi dipertahankan dan motivasi klien \\
& untuk tetap melakukan perawatan diri. \\
\hline
\end{tabular}




\section{BAB 4 \\ PEMBAHASAN}

Setelah penulis melaksanakan asuhan keperawatan kepadaNy. J dengan Gangguan Defisit Perawatan Diri di Kota Dumai-Riau, maka penulis pada BAB ini akan membahas kesenjangan antara teoritis dengan tinjauan kasus. Pembahasan dimulai melalui tahapan proses keperawatan yaitu pengkajian, diagnosa keparawatan, perencanaan, pelaksanaan dan evaluasi.

\subsection{Pengkajian}

Pada pembahasan ini diuraikan tentang hasil pelaksanaan tindakan keperawatan dengan pemberian terapi generalis pada klien deficit perawatan diri. Pembahasan menyangkut analisis hasil penerapan terapi generalis terhadap masalah keperawatan halusinasi pendengaran. Tindakan keperawatan didasarkan pada pengkajian dan diagnosis keperawatan yang terdiri dari tindakan generalis yang dijabarkan sebagai berikut.

Tahap pengkajian pada klien deficit perawatan diri dilakukan interaksi perawat-klien melalui komunikasi terapeutik untuk mengumpulkan data dan informasi tentang status kesehatan klien. Pada tahap ini terjadi proses interaksi manusia, komunikasi, transaksi dengan peran yang ada pada perawat sebagaimana konsep tentang manusia yang bisa dipengaruhi dengan adanya proses interpersonal.

Selama pengkajian dilakukan pengumpulan data dari beberapa sumber, yaitu dari klien dan tetangga dan keluarga klien. Penulis mendapat sedikit kesulitan dalam menyimpulkan data karena keluarga klien jarang mengunjungi klien dirumahnya. Maka penulis melakukan pendekatan kepada klien melalui komunikasi terapeutik yang lebih terbuka membantu klien untuk memecahkan perasaannya dan juga melakukan observasi kepada klien. 
Adapun upaya tersebut yaitu:

a. Melakukan pendekatan dan membina hubungan saling percaya diri pada klien agar klien lebih terbuka dan lebih percaya dengan menggunakan perasaan.

b. Mengadakan pengkajian klien dengan wawancara

Dalam pengkajian ini, penulis menemukan kesenjangan karena ditemukan. Pada kasus Ny. J, klien tampak bau, kotor,tidak rapi, berantakan. Gejala gejala yang muncul tersebut tidak semua mencakup dengan yang ada di teori klinis dari defisit perawatan diri. Akan tetapi terdapat faktor predisposisi maupun presipitasi yang menyebabkan kekambuhan penyakit yang dialami oleh $\mathrm{Ny}$. J.

Tindakan keperawatan terapi generalis yang dilakukan pada Ny. J adalah strategi pertemuan pertama sampai pertemuan ketiga. Strategi pertemuan pertama yaitu pengkajian lansung ke klien sembari wawancara langsung. Strategi pertemuan kedua yang dilakukan pada $\mathrm{Ny}$. J yaitu melatih dalam merawat diri : mandi dan berhias. Strategi pertemuan yang ketiga adalah melatih dalam merawat diri : makan/minum dan BAB dan BAK.

\subsection{Perencanaan}

Perencanaan dalam proses keperawatan lebih dikenal dengan rencana asuhan keperawatan yang merupakan tahap selanjutnya setelah pangkajian dan penentuan diagnosa keperawatan. Pada tahap ini antara tinjauan teoritis dan tinjauan kasus tidak ada kesenjangan sehingga penulis dapat melaksanakan tindakan seoptimal mungkin. Secara teoritis digunakan cara strategi pertemuan sesuai dengan diagnose keperawatan yang muncul saat pengkajian.

\subsection{Implementasi}

Pada tahap implementasi, penulis hanya mengatasi 2 masalah keperawatan yakni: diagnosa keperawatan Defisit Perawatan Diri dan Harga Diri Rendah. Pada diagnosa keperawatan deficit perawatan diri dilakukan strategi pertemuan yaitu pengkajian langsung ke klien. Kemudian strategi pertemuan selanjutnya yang dilakukan yaitu melatih cara perawatan diri : mandi dan berhias. Strategi pertemuan yang ketiga yaitu melatih cara perawatan diri : makan minim dan $\mathrm{BAB} / \mathrm{BAK}$. 


\subsection{Evaluasi}

Pada tinjauan teoritis evaluasi yang diharapkan adalah: Klien mempercayai perawat sebagai terapis, klien menyadari bahwa penting dalam merawat dan membersihkan diri.

Pada tinjauan kasus evaluasi yang didapatkan adalah: Klien mampu membersihkan diri : mandi dan merawat diri : berhias/berdandan, Klien mampu melakukan makna dan minun dengan baik dan benar serta BAB dan BAK dengan baik. Selain itu, dapat dilihat dari setiap evalusi yang dilakukan pada asuhan keperawatan, dimana terjadi penurunan gejala yang dialami oleh $\mathrm{Ny}$. J dari hari kehari selama proses interaksi. 


\section{BAB 5 \\ PENUTUP}

\subsection{Kesimpulan}

Berdasarkan uraian pada pembahasan di atas, maka penulis dapat disimpulkan bahwa:

1. Pengkajian dilakukan secara langsung pada klien dan juga dengan menjadikan status klien sebagai sumber informasi yang dapat mendukung data-data pengkajian. Selama proses pengkajian, perawat mengunakan komunikasi terapeutik serta membina hubungan saling percaya antara perawat-klien. Pada kasus Ny. J diperoleh bahwa klien mengalami gejala-gejala Defisit Perawatan Diri. Faktor predisposisi pada Ny. J yaitu pernah mengalami gangguan jiwa sebelumnya.

2. Diagnosa keperawatan yang muncul pada kasus Ny. J yaitu Defisit Perawatan Diri dan Harga Diri Rendah. Tetapi pada pelaksanaannya, penulis fokus pada masalah utama yaitu Defisit Perawatan Diri.

3. Perencanaan dan implementasi keperawatan disesuaikan dengan strategi pertemuan pada klien Defisit Perawatan Diri dan Harga Diri Rendah.

4. Evaluasi diperoleh bahwa terjadi peningkatan kemampuan klien dalam merawat dirinya yang dialami serta dampak pada penurunan gejala Defisit Perawatan Diri yang dialami.

\subsection{Saran}

1. Bagi Perawat

Diharapkan dapat menerapkan komunikasi terapeutik dalam pelaksanaan strategi pertemuan 1- 3 pada klien Defisit Perawatan Diri sehingga dapat mempercepat proses pemulihan klien.

2. Bagi Institusi Pendidikan

Dapat meningkatkan bimbingan praktek lapangan kepada mahasiswa profesi ners sehingga mahasiswa semakin mampu dalam melakukan asuhan keperawatan pada klien-klien yang mengalami halusinasi pendengaran.

3. Bagi Klien

Laporan ini diharapkan dapat menjadi acuan dan referensi dalam memberikan asuhan keperawatan pada klien dengan Defisit Perawatan Diri 


\section{DAFTAR PUSTAK.}

Erlando, R. P. A. (2019). Terapi Kognitif Perilaku dan Defisit Perawatan Diri: Studi Literatur. ARTERI: Jurnal Ilmu Kesehatan, 1(1), 94-100. https://doi.org/10.37148/arteri.v1i1.9

Hastuti, R. Y., \& Rohmat, B. (2018). Pengaruh Pelaksanaan Jadwal Harian Perawatan Diri Terhadap Tingkat Kemandirian Merawat Diri Pada Pasien Skizofrenia Di Rsjd Dr. Rm Soedjarwadi Provinsi Jawa Tengah. Gaster, 16(2),177-190. http://jurnal.aiskauniversity.ac.id/index.php/gaster/article/view/294

Herdman, T. H. (2012). Diagnosis keperawatan definisi dan klasifikasi 2012-2014.

Jalil, A. (2015). Faktor Yang Mempengaruh Penurunan Kemampuan Pasien Skizofrenia Dalam Melakukan Perawatan Di Rumah Sakit Jiwa. Jurnal KeperawatanJiwa,3(2),70-77. https://jurnal.unimus.ac.id/index.php/JKJ/article/view/3933

Kemenkes RI. (2019). Riset Kesehatan Dasar, RISKESDAS. JAKARTA: Kemenkes RI. https://databoks.katadata.co.id/datapublish/2019/10/08/persebaran-prevalensiskizofreniapsikosis-di-indonesia\#

Nurhalimah. (2016). Modul Bahan Ajar Cetak Keperawatan, 162-170.

Pardede, J. A. (2020). Ekspresi Emosi Keluarga Yang Merawat Pasien Skizofrenia. Jurnal Ilmiah Keperawatan Imelda, 6(2), 117-122. https://doi.org/10.2411/jikeperawatan.v6i2.403

Pardede, J. A., \& Purba, J. M. (2020). Family Support Related to Quality of Life on Schizophrenia Patients. Jurnal Ilmiah Permas: Jurnal Ilmiah STIKES Kendal, 10(4), 645654. https://doi.org/10.32583/pskm.v10i4.942

Pardede, J. A., Ariyo, A., \& Purba, J. M. (2020). Self Efficacy Related to Family Stress in Schizophrenia Patients. Jurnal Keperawatan, 12(4), 831-838. https://doi.org/10.32583/keperawatan.v12i4.1010

Pardede, J. A., Hamid, A. Y. S., \& Putri, Y. S. E. (2020). Penerapan Social Skill Training Dengan Menggunakan Pendekatan Teori Hildegard Peplau Terhadap Penurunan Gejala Dan Kemampuan Pasien Isolasi Sosial. Jurnal Keperawatan,12(3), 327-340. Doi:10.32583/keperawatan.v12i3.782

Pinedendi, N., Rottie, J., \& Wowiling, F. (2016). Pengaruh Penerapan Asuhan Keperawatan Defisit Perawatan Diri Terhadap Kemandirian Personal Hygiene Pada Pasien di RSJ. Prof. VL Ratumbuysang Manado Tahun 2016. JURNAL KEPERAWATAN, 4(2).

Putra, R. S., \& Hardiana, S. (2019). Komunikasi Terapeutik Perawat Pada Pasien Dengan Masalah Defisit Perawatan Diri. In Prosiding Seminar Nasional (pp.152-156). http://prosiding.stikesmitraadiguna.ac.id/index.php/PSNMA/article/view/21

Rochmawati, D. H., Keliat, B. A., \& Wardani, I. Y. (2013). Manajemen Kasus Spesialis Jiwa Defisit Perawatan Diri Pada Klien Gangguan Jiwa di RW 02 dan RW 12 Kelurahan Baranangsiang Kecamatan Bogor Timur. Jurnal KeperawatanJiwa,1(2). https://jurnal.unimus.ac.id/index.php/JKJ/article/view/972

Sutria, E. (2020). Intervention Of Nurse Deficit Self Care In The Skizofrenia Patient: Systematic Review. Journal Of Nursing Practice, 3(2), 244-252. DOI:https://doi.org/10.30994/jnp.v3i2.94

Tumanduk, F. M. E., Messakh, S. T., \& Sukardi, H. (2018). Hubungan Tingkat Kemampuan Perawatan Diri Dengan Tingat Depresi Pada Pasien Depresi Di Bangsal Rumah Sakit Jiwa 
Daerah Surakarta. Jurnal Ilmu Keperawatan dan Kebidanan, 9(1), 10-20. 